Bulgarian Academy of Sciences. Space Research and Technology Institute. Aerospace Research in Bulgaria. 29, 2017, Sofia

\title{
ELECTRIC MOTOR-GENERATORS FOR UNMANNED AERIAL VEHICLES
}

\author{
Pavlin Gramatikov \\ Space Research and Technology Institute - Bulgarian Academy of Sciences \\ e-mail:pgramatikov@space.bas.bg
}

\begin{abstract}
Permanent magnets (PM) are used in the new multi-pole electric generators. Direct connection without a reducer greatly simplifies the design and provides a long life and low weight. To improve the technical parameters of electric generators, are used PM based on rare-earth $\mathrm{Nd}-\mathrm{Fe}-\mathrm{B}$ magnets. The absence of sliding electrical contacts significantly increases life and reliability in comparison with electric generators of direct current and synchronous generators.

Special attention is given to high specific indicators for the developed power per unit of weight. Additional computer simulation has been made. The results of calculating the magnetic field and moments for models of electric motors with permanent magnets are considered. It is shown that the configuration of the magnetic system has a significant effect on the electrical characteristics of the electric generator.
\end{abstract}

\section{Introduction}

Drone hybrid system (DHS) for hybrid drones (HD) is the most promising direction of development of the unmanned aerial vehicles (UAV). Usually HD refers to the aircraft with vertical take-off and landing (VTOL). Hybridity is the combination of several types of power unit in one drone.

Today, the U.S.A. has a "Section 333" of the rules of flight safety. It prohibits UAV from flying beyond line of sight of the operator, which is defined in $480 \mathrm{~m}$ and a height of more than $61 \mathrm{~m}$. In August 2016 entered into force, the $107^{\text {th }}$ section of the Chapter. It allows operators with permission to operate UAV beyond line of sight (up to $32 \mathrm{~km}$ ) and at altitudes of up to $122 \mathrm{~m}$. It is allowed to fly with UAV weighing up to $25 \mathrm{~kg}$. These new rules will help the development of DHS and increase the flight time to 4 hours.

Lithium polymer batteries (Li-Po), which power the majority of UAV can withstand at least $30 \mathrm{~min}$. For the record, Mavic Pro DJI drone has a flight time of about $25 \mathrm{~min}$, the DJI Phantom 4 has about 30 min [1]. Unofficial record of 2015 was set from Energy Technologies, when its hydrogen-powered drone was airborne for $3 \mathrm{~h}$ and $43 \mathrm{~min}$. Hydrogen fuel cells and hydrogen-acid fuel cells are the most 
promising type of power plant for UAVs. They work on the principle of electroplating as a battery, but the fuel (hydrogen) is supplied from the tank. For efficiency, they are much superior to the batteries in the small UAVs. The HYCOPTER is the world's first hydrogen fuel cell powered multi-rotor UAV. It is currently being readied for a record flight endurance of over $4 \mathrm{~h}$, or 8 to 10 times the flight duration of equivalent power systems today [2].

The company Quaternium Technologies, is a leading European brand for long flying drones, through his fuel-electric quadcopter - HYBRiX.20. It set a world record for flight duration - $4 \mathrm{~h}$ and $40 \mathrm{~min}$. This HD is built on the classic by the electric BLDC motors with powerful generator set on the basis of the two-stroke engine, which supports energy in the battery of the drone throughout flight [3].

There are drawbacks for HD on gasoline engine (GE) such as the need to install an ignition system. The electromagnetic field (generated by the ignition system) also causes interference with the control channels and information transfer. Problem can be fixed with the help of additional equipment and a well-designed layout multicopter. For this purpose it is not allowed to place the radio receivers closer than $0.3 \mathrm{~m}$ from the ignition. Another significant disadvantage of the UAVs on the petrol engine is a fire hazard in the event of an accident.

Drones with a hybrid power plant have two types of propulsion:

- Power plant (GE or gas turbine engine, GTE) produces electricity, but in creating the thrust is not involved (hidden in the fuselage).

- The motor or turbine twists the propeller and generator.

The developers of Pegasus Aeronautics give the following example: drone DJI S1000 has a maximum take-off weight of $11 \mathrm{~kg}$ and uses 6S LiPo battery with weight $1.5 \mathrm{~kg}$, with capacity of $16 \mathrm{Ah}$ and can carry up to $5 \mathrm{~kg}$ of payload for $15 \mathrm{~min}$. If we replace the electrical battery with generator GE-30 Range Extender with equivalent capacity $128 \mathrm{Ah}$ and weighs just $0.45 \mathrm{~kg}$ more, will allow DJI S1000 flying time within $2 \mathrm{~h}$ with payloads up to $4 \mathrm{~kg}$ [4].

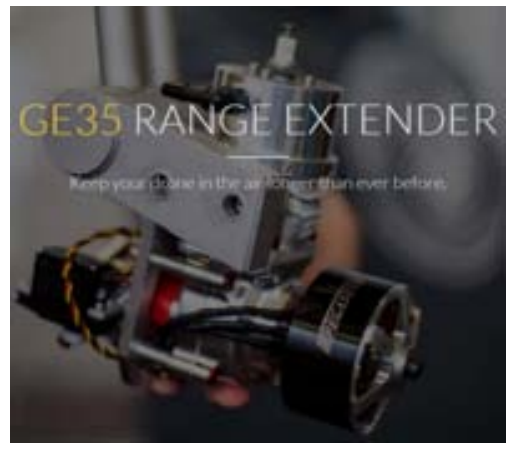

Technical Specifications:

- Base Weight: $2.60 \mathrm{~kg}$

- Max Continuous Power Output: $2000 \mathrm{~W}$

- Max System Output: $4000 \mathrm{~W}$

- Operational Voltage: $24 \mathrm{~V}(6 \mathrm{~S})$ through $50 \mathrm{~V}$

(12S)

- Cooling: Liquid-Cooled, External Radiator

- Starting Method: Self Starting

- Fuel Delivery: Fuel Injected, ECU Controlled

- Interface Protocol: CAN, Serial

- Initial Time Between Overhaul: 200 h.

Fig. 1. GE-30 Range Extender 
The "Yeair!" is the first quadcopter (Table 1) with control of 4 combustion engines (4 DHS) that can be controlled with the accuracy of an electric engine. Unfortunately, combustion engines are not very dynamic. The electric hub shaft is able to start the combustion engine from a small on-board battery. While in flight, it buffers the energy resulting from slowing down the engine and puts it on disposal again if acceleration is needed. Thus, one can end the flight with almost full battery. Malfunctioning of combustion engines or a controlling unit is swiftly compensated for. UAV "Yeair!" has built-in octocopter safety inside the quadcopter. The safe landing is guaranteed in contrast to conventional quadcopters with electric engines only [5].

Table 1. Technical Specifications of quadrocopter "Yeair!"

\begin{tabular}{|l|l|}
\hline Weight & $4.9 \mathrm{~kg}$ empty weight \\
\hline Payload & $5.0 \mathrm{~kg}$ peak load, $3.0 \mathrm{~kg}$ nominal load \\
\hline Speed & $100 \mathrm{~km} / \mathrm{h}$ maximum speed \\
\hline Range & $55 \mathrm{~km}$ maximum range \\
\hline Fuel & $1.5 \mathrm{l}$ fuel tank, $25: 1 \mathrm{gas} /$ oil ratio \\
\hline Engines & $\begin{array}{l}\text { Engines with } 4 \times 1.6 \mathrm{~kW} \text { maximum power }(1 \mathrm{~kW} \text { combustion } \\
\text { engines plus } 600 \mathrm{~W} \text { BLDC engines). Combustion engine (two } \\
\text { stroke with ignition) has } 12000 \mathrm{rpm} \text {. Self controlled engine start } \\
\text { with running control for the combustion engines. The LiPo } \\
\text { Battery for starting the combustion engine has } 4 \mathrm{~S}, 1250 \mathrm{~mA} / \mathrm{h}\end{array}$ \\
\hline
\end{tabular}

DHS with name "H2 UAV Generator" are presented in (Table 2), with 5 times more range and 5 times longer flying time. This DHS consist of: engine, generator with 24 coils and battery, l default fuel tank 3.5 and LiPo Battery 4S $1.8 \mathrm{Ah} 75 \mathrm{C}$. "H2 UAV Generator" has a word record of $2 \mathrm{~h}$ with $3 \mathrm{~kg}$ payload [5]. Hexacopter Gaya 160 Hybrid with "H2 UAV Generator" have range $100 \mathrm{~km}$ and flying time $3 \mathrm{~h}$ is suitable for power line inspection and mapping industry [6].

Table 2. Drone Hybrid System - "H2 UAV Generator"

\begin{tabular}{|l|l|}
\hline Weight & $4.0 \mathrm{~kg}$ w/o Accessories and $5.2 \mathrm{~kg}$ Total \\
\hline Power & $1.8 \mathrm{~kW}$ Continuous $/ 2.0 \mathrm{~kW}$ Max. Power \\
\hline Dimension $(\mathrm{L} \times \mathrm{W} \times \mathrm{H})$ & $260 \times 1312 \times 325 \mathrm{~mm}$ \\
\hline Applicable UAV Types & Multicopters and VTOL Fix-wings \\
\hline Max. Take-off Weight & $18 \mathrm{~kg}$ or UAV suggested \\
\hline Output Voltage & $12 \mathrm{~S}(49 \mathrm{~V}+/-1 \mathrm{~V})$ \\
\hline Fuel consumption & $750 \mathrm{~g} / \mathrm{kw} \cdot h($ hovering $1.5 \mathrm{~L} / \mathrm{h})$ \\
\hline Service Temperature & $-20 \mathrm{to}+40^{\circ} \mathrm{C}$ \\
\hline Ceiling (above the sea) & $2000 \mathrm{~m}$ \\
\hline
\end{tabular}


The "Russell Engine/Generator" (Eng/Gen) is a unique DHS design that offers extreme power density and high efficiency, united with a built-in, large diameter, high efficiency electric generator [7]. Its advantages are: vibration free operation, no torque transferred outside the Eng/Gen case, and sealed construction (waterproof and dustproof). This design reduced internal friction losses, due to: two cycle piston movement; low number of moving parts and low RPM operation. The weight of this Eng/Gen is $45 \%$ of a conventional diesel engine with generator and all related ancillaries. The term $4 \times 2$ relates to a design with 4 cylinders (each firing 2 times in the course of a single revolution) has generator output $73.6 \mathrm{~kW}$ and operating speed $1200 \mathrm{rpm}$. The "Russell Eng/Gen" is predicted to a power density of $100 \mathrm{~kW} / \mathrm{l}$ which compares with $50-60 \mathrm{~kW} / \mathrm{l}$ for typical four stroke automobile engines [7].

\section{Materials and methods}

Electrical machine is an electromechanical device designed to convert either mechanical energy to electric (electric generator), or electric energy into mechanical (electric motor). The principle of operation of electric machines is based on the laws of electric and magnetic phenomena: the electromagnetic induction law and the Ampere law. The essence of the law of electromagnetic induction as applied to electric machine is that when a conductor moves in a magnetic field with velocity $\boldsymbol{v}$ in directions perpendicular to the vector of magnetic induction $\mathrm{B}$, there is induced electromagnetic field $\mathrm{E}$ :

(1) $\quad \mathrm{E}=$ B.l.v,

where $\boldsymbol{I}$ is the active length of the conductor, i.e. a part of its total length, in the magnetic field.

If the conductor is closed, an electric current $I$ will appear in it. As a result of the interaction of this current with an external magnetic field, the electromagnetic force $F_{e m}$ will act on the conductor, which is determined by the Ampere law:

$$
\mathrm{F}_{\mathrm{em}}=\text { B.l.I . }
$$

With uniform motion of the conductor, the forces $\mathrm{F}$ acting on the conductor are equal to $F_{\boldsymbol{e m}}$. Multiplying both sides of the equality by the velocity of the conductor $\boldsymbol{v}$, we obtain equality [8]:

$$
\text { F.v }=\text { B.l.I.v }=\text { E.I } .
$$

The left-hand side of (3) determines the value of the mechanical power expended on moving the conductor in a magnetic field; the right part - the value of the electric power, developed in a closed loop by an electric current. Electrical 
machines can be multi-phase or single-phase. Asynchronous machines, depending on the design of the winding of the rotor, can be fitted with a short-circuited or phase rotor. Synchronous machines and collector machines with constant current, depending on the way in which they create the magnetic field are two types - with winding excitation and with permanent magnets.

The efficiency can reach significant values: in machines with a very large unit capacity, it can reach $99.5 \%$, in machines of medium power $70-90 \%$. The exception is electric machines of low power (not exceeding a few hundred Watts), the efficiency of which can be from 20 to $60 \%$. To improve the technical parameters of electric generators, $\mathrm{PM}$ are used, based on rare-earth $\mathrm{NdFeB}$ magnets. They have residual magnetic induction $\mathrm{B}_{\mathrm{r}}=1.2-1.45 \mathrm{~T}$ and operating temperatures up to $150^{\circ} \mathrm{C}$. Electric generators with PM have several advantages:

- The possibility of obtaining high values of the longitudinal component of the magnetic induction in the working gap,

- Contactless and lack of nodes that require maintenance. The absence of sliding electrical contacts significantly increases life and reliability in comparison with electric generators of direct current and synchronous generators,

- High efficiency,

- High specific indicators for the developed power per unit of weight.

Direct connection without a reducer greatly simplifies the design and provides a long life and low weight. At a wind with speed of $13 \mathrm{~m} / \mathrm{s}$ on the shaft of one windmill, a power of about $0.95 \mathrm{~kW}$ was obtained (from surface $1 \mathrm{~m}^{2}$ was obtained $300 \mathrm{~W}$ ). When the rotational speed is $100-150 \mathrm{rpm}$, slow-moving multi-pole electric generators on permanent magnets are used [9]. In the boring of the stationary part of the asynchronous motor - stator, there is a rotating part of the motor - a rotor, consisting of a shaft, a core and windings. The winding of the rotor is a short-circuit structure consisting of several aluminum rods (in example with number 8), located in the longitudinal grooves of the rotor core and closed on both sides. The results of calculating the magnetic field and moments for three models of electric motors with permanent magnets are considered. It is shown that the configuration of the magnetic system has a significant effect on the torque characteristics of the electric motor [10]. The rotors in Model 1, are made in the form of an 8-pole, Model 2: 8-pole and for Model 3: 4-pole magnetic system. All three models of three-phase motors have stator phases included as follows: A (+), B (0), and C (-). Switching phases of the motor must be from three non-contact sensors. Every $15^{\circ}$ for Model 1 and 2, and every $30^{\circ}$ for Model 3 there is a change in the status of sensors and a command is issued to enable the respective phases of the motor. Algorithm switching is: A (+), B (0), C (-); A (+), B (-), C (0); A (0), $\mathrm{B}(-), \mathrm{C}(+)$; $\mathrm{A}(-), \mathrm{B}(0), \mathrm{C}(+)$ and thus, within the zone switching includes only two phases in accordance with a predetermined algorithm. Switching zone 1 is equal to $15^{\circ}$ (corresponds to the 8-pole models) and the area switching 2, is equal to $45^{\circ}$. In the commutation zone, the torque for Model 1 is $52 \mathrm{Nm}$, for Model 2, 
$46 \mathrm{Nm}$ and for Model 3, $25 \mathrm{Nm}$. The mass of magnets is $\mathrm{M} 1=2.88 \mathrm{~kg}$, M2 $=2.1 \mathrm{~kg}$ and M3 = $1.05 \mathrm{~kg}$. Comparing Models 1 and 2, increasing the mass of magnets for 1.37 times allowed increasing the torque only by 1.1 times. For the purpose of limiting tooth pulsations, various methods are used. One of them is the execution of the bevels on the rotor. Another way to reduce the magnitude of the pulsation of the electromagnetic moment is the profiling of the ferromagnetic poles according to a predetermined law or the shaping of the special shape of the poles on the rotor [10].

Asynchronous and reluctance machines can also be used for generating. Vehicle generators can be used to add torque for motoring as well. Traction motors can be used as generators during braking to convert kinetic energy to electrical energy. Asynchronous traction motor is used also for braking. Claw Pole alternator is the most popular-over 80 million produced in 2014 (not counting trucks). SR machines can be used as generators but the regulation of the voltage is more complex than the other machine types. Electric machines power density comparison: TESLA - $4.5 \mathrm{kw} / \mathrm{kg}$, BMW i3 - $2.5 \mathrm{kw} / \mathrm{kg}$, Siemens Aero PM motor $5 \mathrm{kw} / \mathrm{kg}$. Permanent magnets can only produce a maximum flux density of $1.4 \mathrm{~T}$. Soft materials (electrical steels) become saturated at maximum flux densities in the range of 2.1 to $2.4 \mathrm{~T}$. When number of stator poles is doubled, the back iron flux is cut in half. Yoke thickness and stator overal diameter (OD) increases with decreasing pole numbers with a fixed stator slot depth and rotor OD (the example on Fig. 2 is with fixed rotor diameter which reduces the stator OD) [11].

On Fig. 3 are given 4 most popular motor-generators machines - RSM, SRM and PM machines typically utilize boost converters for voltage, frequency and power regulation. SR machines can be used as generators but the regulation of the voltage is more complex than the other machine types [11]. Hybrid Starter Generator (HSG) are used in new cars - Sonata, KIA Optima Hybrid. Toyota 2004 Prius has separated PM synchronous generator and PM synchronous traction motor on the same motor shaft. Toyota 2010 Prius has PM generator 12 slot, 8 IPM poles, V shaped [12].

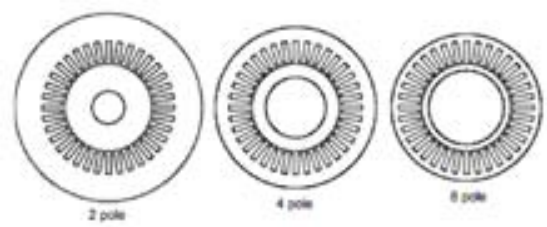

Fig. 2. Yoke thickness and stator versus stator pole
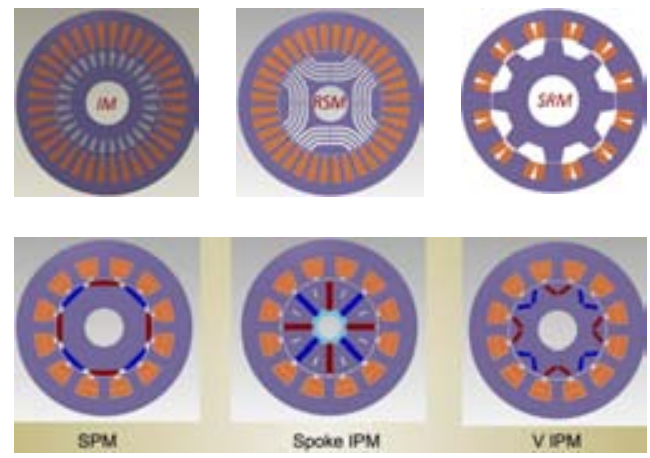

Fig. 3. Generators with three phase stators 
To improve drive train availability for applications in electric vehicles, the article proposes the design of 6-phase permanent magnet machine as two independent 3-phase windings, Fig. 4. A number of possible phase shifts between two sets of 3-phase windings due to their slot-pole combination and winding configuration is investigated and the optimum phase shift is selected [13]. The 6-phase motor can operate as a single unit, in which the stator windings are excited with 6-phase balanced sinusoidal currents of the same magnitude and frequency but having a phase shift of $60^{\circ}$ electrical with respect to each other. However, 6-phase motor can also be controlled as two separate and independent three-phase systems. Each set of the three-phase system is excited with 3-phase balanced sinusoidal currents of the same magnitude and frequency but having a phase shift of $120^{\circ}$ electrical with respect to each other [13].

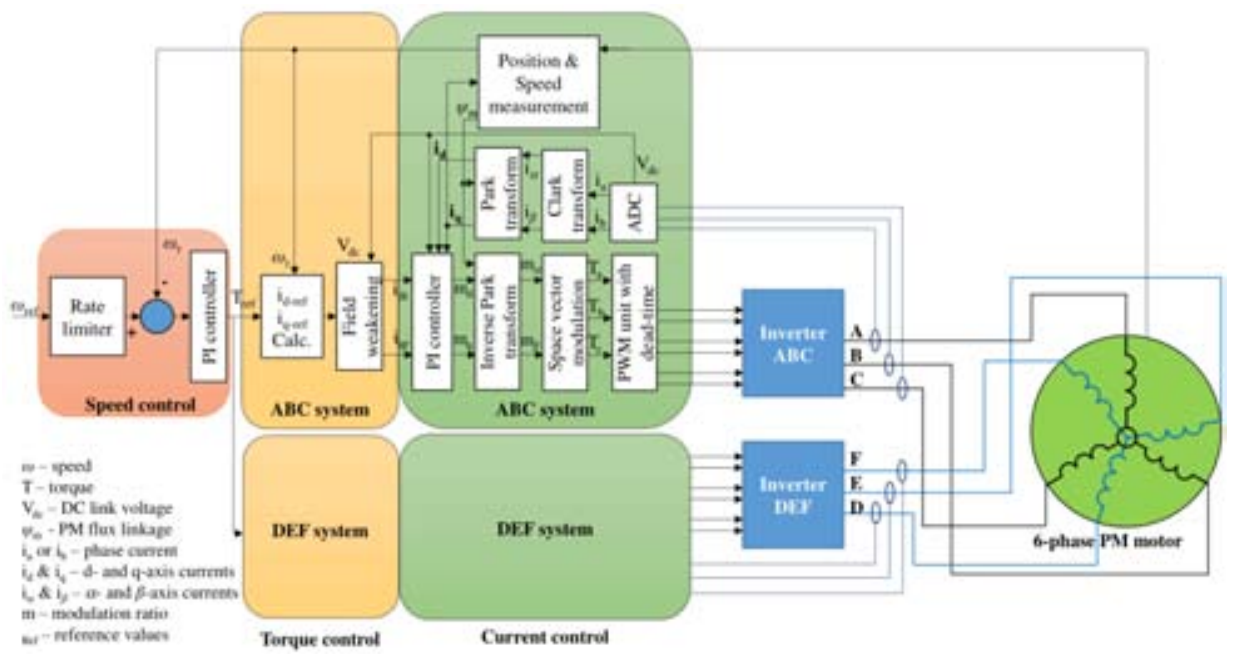

Fig. 4. Schematic of inverter control system having independent control for both set of three-phase system of six-phase permanent magnet machine

Here are presented the equations of the main parameters needed in the modelling of double-star PM machines. In a magnetically linear system (stator), the self-inductance $\mathrm{L}$ of a winding is the ratio of the flux $\psi$ linked by a winding to the current $I$ flowing in the winding with all the other winding currents zero. The selfinductance of a winding $i$ can be expressed as follows [17]:

(4) $\mathrm{L}_{i}=\psi_{i} / \mathrm{I}_{i}$

Similarly, the mutual inductance linking the windings $i$ and $j$ results in the following expression: 


$$
\mathrm{M}_{i j}=\psi_{j} / \mathrm{I}_{i} \text {. }
$$

The PM machines with buried magnets correspond to salient pole machines, in which the inductances depend on the rotor position. In such machines the fundamental wave of the self-inductance of a stator winding varies by $2 \theta_{e}$. The dependency can be taken into account in the analytical expression of inductances with an inverse air-gap function. The inverse air-gap function is expressed with the following approximation [17]:

$$
\begin{aligned}
& g\left(\varphi_{s}-\theta_{e}\right)^{-1}=\epsilon_{1}-\epsilon_{2} \cdot \cos \left(2 \varphi_{s}-2 \theta_{e}\right) . \\
& L_{i}=\mu_{0} \text {.r.l } \int_{0}^{2 \pi} \mathrm{N}_{i}\left(\varphi_{s}\right)^{2} g\left(\varphi_{s}-\theta_{e}\right)^{-1} d \varphi_{s},
\end{aligned}
$$

where $l$ is the stack length, $\boldsymbol{r}$ is the effective radius of the stator bore, and $\boldsymbol{\mu}_{\boldsymbol{0}}$ is the permeability of vacuum $\left(4 \pi 10^{-7} \mathrm{Vs} / \mathrm{Am}\right)$. The mutual inductance linking any two stator windings $i$ and $j$ can be expressed similarly where $\varphi_{\mathrm{s}}$ is the stator circumferential position and $\theta$ e is the rotor position. The variables $\epsilon_{1}$ and $\epsilon_{2}$, defined with the help of the minimum and maximum air-gap lengths $g_{\min }$ and $g_{\max }$, respectively. According to [17] the torque characteristic of a multiphase machine, the armature of which consists of two three-phase winding sets having a displacement of $30^{\circ}$ between the sets, is substantially better than for 0 - or 60degree displacements. Moreover, by supplying the two three-phase sets displaced by $30^{\circ}$ with two three-phase inverters instead of one set and one inverter, the amplitude of the pulsating torque component was reduced and the frequency was shifted to 12 times the supply frequency [17]. In [14] it is describes the development of new winding configurations for 6-phase permanent magnet (PM) brushless machines with 18-slot, 8-pole, that eliminate and/or reduce undesirable space harmonics in the stator magneto motive force, see Fig. 5 and Fig. 6.

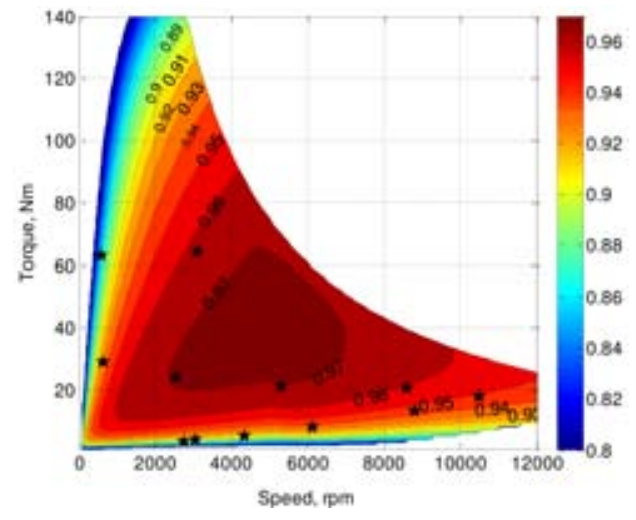

Fig. 5. Predicted efficiency map of optimized 6-phase, 18-slot, 8-pole IPM motor

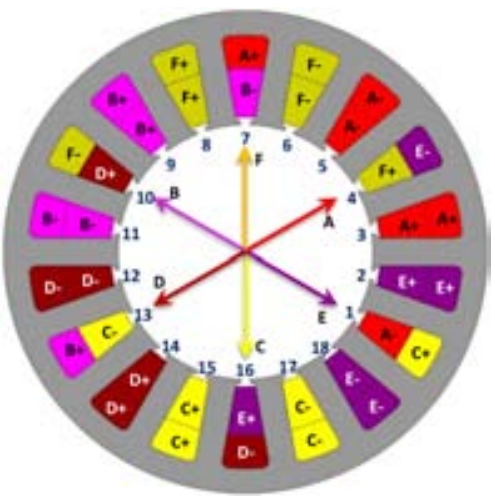

Fig. 6. Schematic of 6-phase, 18slot, 8-pole winding configuration 
The automotive industry is producing new Hybrid Electrical Vehicles (HEV) and pure Electric Vehicles (EV). Simulation of the BMW i3 Traction Motor is given on Fig. 7, with software MotorSolve [15]. It is assembled data from the Oak Ridge National Laboratory (ORNL) and from BMW to develop a MotorSolve model of the 2016 BMW i3 traction motor. The 2016 BMW i3 traction motor is a 12 pole/72 slot motor with an IPM rotor, rated at $125 \mathrm{~kW}$. The rotor was designed to have a high saliency ratio; correspondingly the reluctance torque component was high as a consequence. It was also designed to have a very sinusoidal back EMF which is rare in motor designs.

Software analysis of the 2010 Toyota Prius Traction Motor $(60 \mathrm{~kW}$, rotation speed $13500 \mathrm{rpm}$ ) can be modeled by importing a CAD created rotor DXF file in MotorSolve or in MagNet (Fig. 8). The performance of the magnetics within a motor the Toyota 2010 Prius is $37.5 \mathrm{mV}$ rms per $1 \mathrm{rpm}$. At $4000 \mathrm{rpm}$ this is $150 \mathrm{~V}$ rms. MotorSolve predicts the Back EMF within $2 \%$ of the measured values [16]. Toyota Prius 2010 PM generator $42 \mathrm{~kW}$ have 12 stator slot, 8 IPM poles (V-shaped), rotor mass is $3.93 \mathrm{~kg}$ and stator mass $8.53 \mathrm{~kg}$. Bi-directional dc-dc converter, for Prius 2010 PM generator, has the following parameters: 200 Vdc, $27 \mathrm{~kW}$. Battery is fan cooled, Ni-Mh with $201.6 \mathrm{Vdc}$ and 6,5 Ah. It is given comparison between Specific power density of current piston engines, turbines and electric motors, Fig. 9 [16].
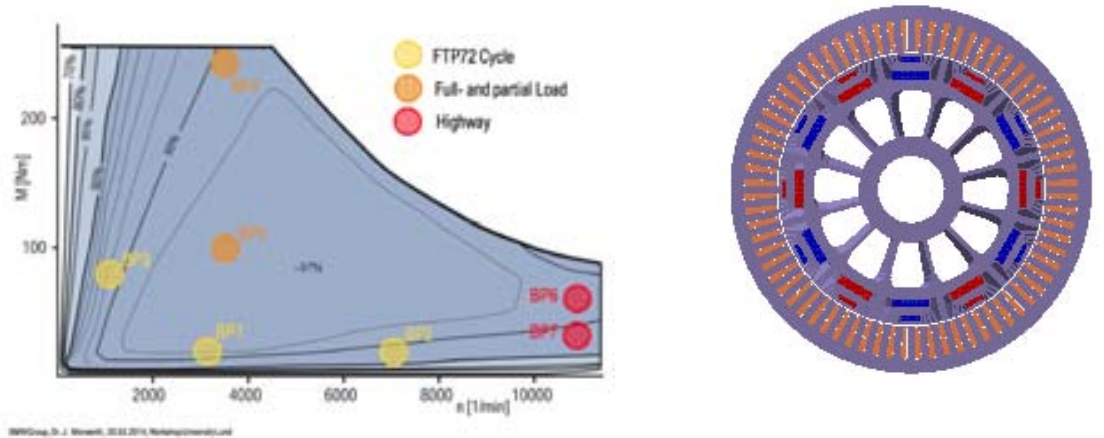

Fig. 7. Efficiency of BMW i3 traction motor with IPM rotor


Fig. 8. Efficiency of Toyota traction motor with IPM rotor 


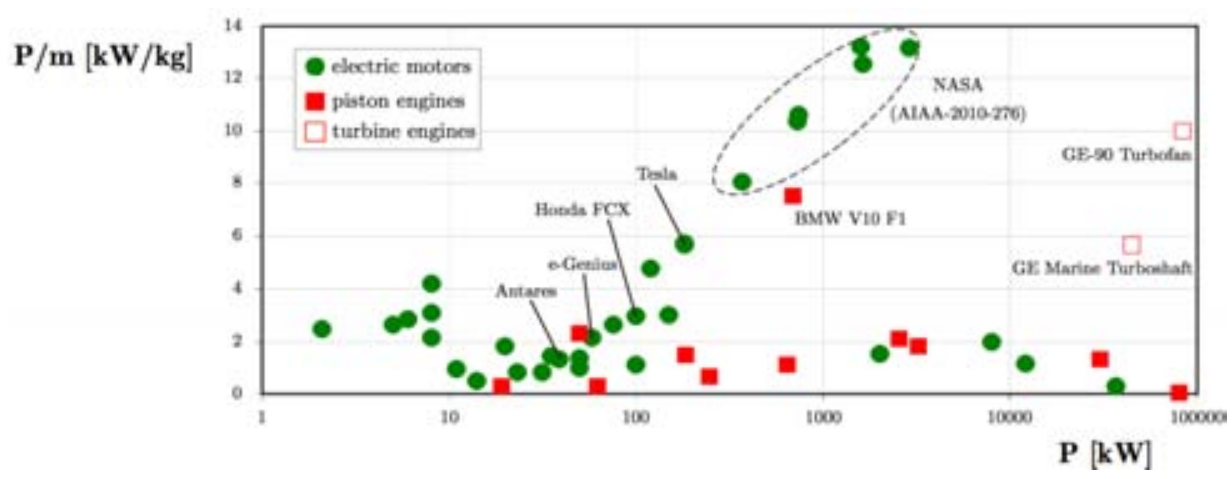

Fig. 9. Specific power density of current piston engines, turbines and electric motors

\section{Results}

A purely electric UAV, (VTOL type), designed with 5 electric motors (4 for vertical take-off and 1 for horizontal flight) is be the objective of this work. The capabilities of without doubt helicopters are more versatile than fixed-wing and vertical take-off and landing (VSTOL) aircraft, when it is required to switch between several flight modes during a mission. The efficiency of VTOL aircraft during hovering is much less than helicopters due to the relatively small effective rotor area. The electric UAV is for a flight mission where the cruise time is much greater than the hover time pointing the choice towards a VSTOL aircraft, which can be thought of as a cross between a rotary and fixed-wing UAV. At least half the loiter energy of the electric UAV (E UAV) is required for the hybrid-electric UAV, one half of the E UAV battery is replaced by the hybrid-electric UAV propulsion weight and fuel. The lighter the propulsion weight, the more fuel can be put onboard and hence the more total energy is available on-board. As can be seen from Fig. 6, when the propulsion is one-third of the total E UAV battery weight, the total energy on-board is over three times that of the E UAV [18]. The generator S676-500U-01 has a mass of $1.15 \mathrm{~kg}$ and rated power is $2250 \mathrm{~W}$ at $7500 \mathrm{rpm}$. He will supply electric motor U8 kv170, with a mass of $5 \times 0.242 \mathrm{~kg}, 1300 \mathrm{~W}_{\max }$ for propeller. The O.S. 46FX is a glowplug reciprocating engine, with $1.39 \mathrm{~kW} / \mathrm{kg}$, at $17000 \mathrm{rpm}$, with mass of $1.66 \mathrm{~kg}, 2307 \mathrm{~W}_{\max }$. The battery is with nominal voltage of 22.2, $8 \mathrm{Ah}$, with mass of $1.66 \mathrm{~kg}$. If the multicopter with target mass $11.2 \mathrm{~kg}$ flight is only with battery, endurance is $38 \mathrm{~min}$. But with DHS on board, with fuel $2.21 l$, endurance is $61 \mathrm{~min}$ [19]. 


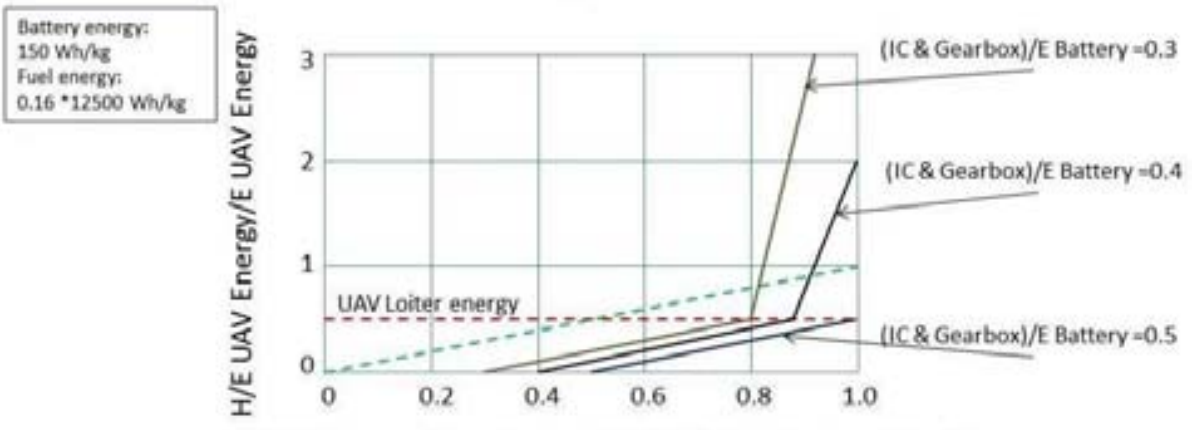

H/E UAV Propulsion System Weight/E UAV Battery Weight

Fig. 10. Propulsion system considerations

\section{Discussion}

It was selected circuit with 6 rectifiers, (Larionov star, six-pulses), which will give for a 3-phase system a voltage absolute pulsation amplitude of $14 \%$. For the selected 6-phase permanent magnet generator, 12 rectifiers (two Larionov star, twelve-pulses, in the serial inclusion) will give pulsation $4 \%$.

\section{References}

1. Этот гибридный дрон установил новый неофициальный рекорд длительности полета. https://lenskii.ru/technologies/gadgets/etot-gibridnyj-dron-ustanovil-novyjneofitsialnyj-rekord-dlitelnosti-poleta/ (available online: 17 September 2017)

2. HYCOPTER. https://www.h3dynamics.com/products/hycopter/ (online accessed: 10 January 2018)

3. HYBRiX.20: гибридный квадрокоптер установил рекорд по продолжителности полета. https://dronomania.ru/news/hybrix-20-gibridnyj-kvadrokopter-ustanovilmirovoj-rekord-po-prodolzhitelnosti-poleta.html (online accessed: 10 January 2018)

4. GE35 Range Extender. http://www.pegasusaero.ca/ge35-range-extender

5. yeair! Table of Specs. http://www.yeair.de/specs/ (online accessed: 10 January 2018)

6. Richen Power. H2 UAV Generator. http://www.richenpower.com/uploads/file/H2en.pdf (online accessed: 10 January 2018)

7. Russell Energy Corporation. URL: http://www.russellenergy.com/includes/businessopportunity.php (online accessed: 10 January 2018)

8. Кацман, М.М. Справочник по злектрическим машинам: Учеб. пособие для студ. образоват. учреждений сред. проф. Образования - М.: Издательский центр «Академия», ISBN 5-7695-1686-0, 2005, с. 480.

9. Гребеников, В.В. Электрогенераторы с постоянными магнитами для ветроустановок и микро-ГЭС, УДК 621.313.17, Гідроенергетика України, ISSN 1812-9277, 1/2011, с. 43-48. 
10. Гребеников, В.В., М.В. Прыймак, Исследование влияния конфигурации магнитной системы на моментные характеристики электродвигателей с постоянными магнитами, Електротехніка та електроенергетика, 2009, 2, 5760. ISSN 1607-6761, URL: http://elcut.ru/publications/grebenikov1.pdf

11. Hendershot, J.R., WORKSHOP Generator designs including choices for hybrid vehicles, CWIEMIE Chicago, 4-6 October 2016, DESCC Chicago. https://www.coilwindingexpo.com/chicago/_media/pdfs/jim_hendershot_wed_5t h_october.pdf (online accessed: 10 January 2018)

12. Hendershot, J.R., Designing a PM Generator for a hybrid vehicle with MotorSolve, 810 November 2016, Aria Resort and Casino, Las Vegas. https://www.infolyticaengage.com/wp-content/uploads/2017/01/Design-a-PMGenerator-by-J-Hendershot.pdf (online accessed: 10 January 2018)

13. Patel, V.I., J. Wang, et al., 6-phase Fractional Slot per Pole per Phase Permanent Magnet Machines with Low Space Harmonics for Electric Vehicle Application, 2014, 50, 4, 2554-63. ISSN 0093-9994. DOI: 10.1109/TIA.2014.2301871

14. Patel, V.I., J., Wang, D.T., Nugraha, R. Vuletic, and J. Tousen, Enhanced availability of drivetrain through novel multiphase permanent-magnet machine drive, IEEE Transactions on Industrial Electronics, 2016, 63, 1, 469-480. ISSN 0278-0046 DOI: 10.1109/TIE.2015.2435371

15. Simulation of the BMW i3 Traction Motor. https://www.infolytica.com/en/ applications/ex0214/ (online accessed: 10 January 2018)

16. Hendershot, J.R., Motor Solve analysis of the 2010 Toyota Prius Traction Motor, Hilton Rosemont, Chicago O’Hare, 27 October 2015. https://www.infolytica.com/Images/applications/engage2015/JamesHendershot_Pr ius.pdf (online accessed: 10 January 2018)

17. Kallio, S., Modeling and Parameter Estimation of Double-Star Permanent Magnet Synchronous Machines, Lappeenranta University of Technology, ISBN 978-952265-563-9, ISBN 978-952-265-564-6 (PDF), ISSN-L 1456-4491, ISSN 14564491, Lappeenranta 2014, 68 p.

18. Jaeger, M., D. Adair. Conceptual design of a high-endurance hybrid electric unmanned aerial vehicle, 11 p. DOI: 10.1016/j.matpr.2017.04.018 (available online: 20 June 2017)

19. Donateo, T., L. Spedicato, and D. Pio Placentino, Design and performance evaluation of a hybrid electric power system for multicopters, Energy Procedia, 2017, 126, 1035-42. DOI: 10.1016/j.egypro.2017.08.310 


\section{ЕЛЕКТРИЧЕСКИ МОТОР-ГЕНЕРАТОРИ ЗА БЕЗПИЛОТНИ ЛЕТАТЕЛНИ СРЕДСТВА}

\section{П. Граматиков}

\section{Резюме}

В настоящата статия се разглеждат устройството и принципа на работа на съвременни електрически мотор-генератори, подходящи за използване в различни по размер и конструкция безпилотни летателни средсва. Предложеното решение за използване на двигател с вътрешно горене за стопроцентно захранване на всички бордни електрически мотори за създаване на подемна сила за вертикален и хоризонтален полет може да се използва в хибридни БЛА, при което времето на полет се очаква да се увеличи 2 до 4 пъти, в сравнение с това при използване само на електрически батерии. Предлага се електронният контролер на мотор-генератора да обезпечи работа му в режим стартер и режим производсво на електроенергия. Посочени са софтуерни продукти за компютърна симулация на процесите в електрическите мотор-генератори. 